\title{
Curriculum conception, implementation and evaluation:
}

\section{An experience}

\author{
Cecília Galvão, Cláudia Faria, Sofia Freire, Mónica Baptista \\ Institute of Education, University of Lisbon, \\ Alameda da Universidade, 1649-013, Lisbon, Portugal
}

\section{Introduction}

We live today difficult, uncertain and complex times. The secure jobs no longer exist and citizens have to be prepare to get adapted to different (and sometimes opposite) contexts. So, in this rapidly changing world, citizens' knowledge must also be comprehensive and based on multiple capabilities. According to AMA (2010), the accelerated technological change and globalization of the market require individuals with expertise in various areas, flexibility, creativity, communication skills and the ability to learn throughout life. In this scenario of change, of complexity and of unpredictability, and in order to promote students' personal fulfillment and active citizenship, school have to provide learning experiences that facilitate the development of communication and digital skills; of basic competences on mathematics, science and technology; of social and civic competences; a sense of initiative and entrepreneurship; metacognition, cultural awareness and expression (EP\&C, 2006).

Science education can play a crucial role in this regard. In a society marked by science and technology, in which citizens are increasingly called to make decisions 
concerning scientific issues that affect their lives and the society they live in, it is essential to equip citizens with fundamental scientific knowledge and knowledge about the processes of scientific activity. In seeking to achieve these purposes, science education can also be a means to foster the development of communication skills, critical thinking, problem solving and decision making, among others.

This way of understanding the goals of science education requires a new understanding of how to organize curricula. And indeed, we have been observing a recent trend towards competence-based teaching and learning, which requires significant changes in science school curricula. International recommendations refer that teachers should organize challenging learning situations, which are meaningful and related with students' social reality. Besides, those recommendations mention that teachers should provide students with careful guidance in learning situations related to problem solving and decision-making in order to promote self-regulated learning (Autio, Kaivola, \& Lavonen, 2007; EU, 2004; Osborne \& Dillon, 2008; UNESCOICSU, 1999). Finally, inquiry-based strategies have been highlighted as having the potential to increase students' engagement in science at all levels and to provide opportunities for competences' development (European Commission \& High Level Group on Science Education, 2007; Osborne \& Dillon, 2008).

Aligned with the emergent goals of science education and with the new trends in curricular studies, the Portuguese science curriculum was reorganized as part of a broader curricular reorganization, in an extended process that started in 1997 and ended in 2001. This was a particular important process that introduced significant changes regarding conceptions of teachers' role and the teaching-learning process. The 
curricular reorganization proposed a more student-centred curriculum, focused on the development of essential competences. Besides, teachers were conceived as active elements, which were expected to interpret the curriculum guidelines and to adapt it to different contexts and students, in order to improve students' successful learning. These were major changes in a very traditionally centralized system that expected that the curriculum would be uniformly implemented across the country, based on the notion of the teachers as a passive player of a curriculum organized according to fixed guidelines and goals, and based on long lists of contents that teachers were supposed to transmit to students.

In addition to introducing new ideas and principles of curricular organization, the process of curricular reorganization also sought to trigger a thorough discussion of those ideas and principles, involving universities, schools and teachers, in order to facilitate change. From this process emerged a new curricular organization and the curricular documents that guide Portuguese basic education. In particular, with respect to basic science education, the main documents are the National Curriculum of basic science education (DEB, 2001a) and the national curriculum guidelines for Physical and Natural sciences for the 3rd cycle (DEB, 2001b).

With this chapter we intend to describe the process of conception and implementation of the Portuguese basic science education curriculum, as not only it introduced several innovations, such as the ideas of flexible management of the curriculum and of educational experiences for developing competences, as it also followed a particular model of curricular implementation, adapted to the unique Portuguese context. Furthermore, from the analysis of the process of implementation of 
the new curricular ideas, we can learn about the process of appropriation of new curricular concepts by teachers, and so to add onto the discussion about educational change.

\section{The Portuguese Science Curriculum: Conception and Implementation}

\subsection{Science Curriculum Characterization}

The science curriculum for the third cycle of basic education (12 to 14 years old) was officially implemented in 2002/2003 (Galvão \& Lopes, 2002), with the main goal of motivating the development of learning environments that would encourage students to raise questions about the natural world around them, as well as about human action over the world and about the environmental and cultural impact of science and technology, and to make students gain a general understanding of broad explanatory frameworks of science as well as of its procedures (Galvão, Freire, Lopes, Neves, Oliveira \& Santos, 2004). Furthermore, this curriculum assumes a constructivist perspective, and it emphasizes Science-Technology-Society-Environment (STSE) approaches and inquiry-based learning (Galvão \& Freire, 2004). Finally it encourages the interdisciplinary exploration of the topics, in order to promote an integrated vision of the natural world (DEB, 2001b), and the creation of complex learning experiences facilitating the development of essential competences (Galvão et al., 2004).

In accordance with these goals and principles, the curriculum underwent reorganization, getting closer two disciplines that traditionally were treated as separated subjects: (i) Natural Sciences (NS) (which incorporates biology, geology, environmental 
education and health education) and (ii) Physics and Chemistry Sciences (PCS) (which incorporate physics, chemistry and environmental education) (Galvão, Reis, Freire \& Oliveira, 2007). Furthermore, in order to overcome a disciplinary logic, it was organized around four topics: "Earth in space", "Earth in transformation", "Sustainability on earth" and "Better living on earth". These topics are meant to be explored flexibly (and when possible, also interdisciplinary) during the three years of the third basic education period (DEB, 2001b). While exploring these themes through complex learning situations, students are expected to construct substantive knowledge concerning science, and also to develop other important competences, such as methodological, reasoning and critical thinking and communication (DEB, 2001a, 2001b).

So, other important introduced changes were: learning experiences for enacting students' competences and rethinking assessment accordingly, and the idea of flexible management of the curriculum, requiring a culture of collaboration and articulation between the teachers.

The overall national curriculum was based on Perrenoud's (1997) definition of competences as "the integration of knowledge and skills developed in complex learning situations" (Galvão et al., 2007). Within a competence based curriculum framework, the goal is to promote the integrated development of both capacities and attitudes that enable the use of knowledge in different situations, especially complex ones (DEB, 2001a), through the creation of contexts that enact students' comprehension, personal meaning construction and enjoyment with learning (Abrantes, 2001). 
In what concerns specifically the science curriculum, students are expected to developed a set of competences, such as substantive, methodological and epistemological knowledge, reasoning and communication, social and scientific attitudes, and lifelong learning skills (DEB, 2001a, b; Galvão et al., 2004). These competences will enable students to act autonomously in the outside world, to participate critically in society and to make informed and reasoned decisions, as is the explicit goal of the science curriculum (Galvão et al, 2004). In order to accomplish this, the science curriculum proposed a set of learning experiences, such as observing the surrounding environment, gathering and organizing materials, planning and developing different types of research, designing projects, carrying out experimental activities and using different instruments for observation and measurement, applying scientific knowledge to everyday situations, and carrying out debates on controversial and contemporary issues (DEB, 2001a, b).

Within this new context centred on the development of competences, teachers were encouraged to rethink students' assessment. The idea is that assessment should not only be a means of certifying learning, but also it should also work as a regulatory tool of pedagogical practices (Abrantes, 2001). In what concerns specifically the science curriculum, assessment was conceived as a way of helping students to regulate their own learning and at the same time as a means to facilitate teachers decisions concerning their own practices, strategies and learning situations (DEB, 2001a, b). So the emphasis was no longer only on the product but also on the process of learning, following the idea of formative learning (Black \& Wiliams, 1998a, b). 
The logic of this competence-based curriculum places a heavy burden on teachers, as interpreting and developing curriculum guidelines are seen as within the teacher's responsibility. Indeed in order to facilitate competences development, teachers have to strategically and intentionally design complex and interdisciplinary learning experiences, which involve students in problem solving, decision making discussion and negotiation processes (DEB, 2001a, b; Galvão et. al, 2004), and to adequately assess the process of competences development. So within this framework, teacher is no longer expected to act as a technician who passively plays the central directions, but as a reflective practitioner, who interprets the guidelines, who articulates with other educational agents, who diversifies strategies and manages the situations in a flexibly and local way, in order to reach out to all students, improving learning (Abrantes, 2001, DEB, 2001a, b).

In conclusion, the reorganization of the national curriculum introduced several new ideas and principles, such as the notion of competence, the development of adequate learning experiences, an emphasis on formative assessment of students, and the idea of flexible management of the curriculum. In order to make teachers familiar with the concepts and principles and also to promote changes in teachers' practices and conceptions, the reorganization of the Portuguese curriculum of basic education involved a complex and extended process of implementation, as it will be described next.

\subsection{Science Curriculum Implementation}


The process of implementation of the science curriculum was characterized by a model that stood between the mutual adaptation perspective and curriculum enactment perspective (Galvão et al., 2004). According to the first approach, the implemented curriculum results from mutual adaptations emerging from the users, given their interests, needs and competences, and also emerging from the central agencies. Thus, the adjustments that occur in the curriculum are made not only by central agencies, but also by the schools and in the context of the classroom, and thus imply "a certain amount of negotiation and flexibility on the part of both designers and practitioners" (Snyder, Bolin, \& Zumwalt, 1992, p. 410). In comparison, according to the approach curriculum enactment, the curriculum is understood "as the educational experiences jointly created by student and teacher" (Snyder et al., 1992, p. 418). Thus, the teacher has the role of the curriculum maker who, together with his students, is increasingly responsible for developing educational experiences (Snyder et al., 1992).

In the Portuguese case, the movement of curricular reorganization took place across the country, under the direction of the Ministry of Education, but simultaneously it sought to involve schools and teachers in the process (Figure 1). So, initially, a team of University professors and school teachers was formed, with the goal of designing a curriculum. While the documents were being produced, several consultants belonging to other universities, other primary and secondary schools and representatives of scientific societies and associations, gave their opinion (Galvão et al., 2004). In this stage, concepts such as competence, flexible management of curriculum, and formative assessment, were deeply discussed. 
In a second stage, the proposed innovations were carried out in some Portuguese schools before being extended to the whole country. This process began with 93 volunteer schools from various locations in Portugal, and this number increased after two years to 184 schools (Galvão \& Lopes, 2002). Over these years, meetings were held to exchange materials and experiences of the schools involved, with the objective of discussing the difficulties, learning, criticism and the different arguments for and against the curriculum proposals (Galvão et al., 2004). Soon after the entry of the national curriculum guidelines for Physical and Natural Sciences, this process of curriculum change was stopped abruptly due to government change. As a result there was no time to make a systematic monitoring of schools and teachers in order to facilitate change and neither to develop an assessment process after three years of implementation, as originally planned. Moreover, the learning process developed from the public discussions, seminars and conferences was not released to the general public (Galvão et al., 2004). 


\begin{tabular}{|c|c|c|}
\hline 1997 & $1998-2001$ & $2002-2003$ \\
\hline $\begin{array}{l}\text { - designing the } \\
\text { curriculum }\end{array}$ & $\begin{array}{l}\text { - Implementation of the } \\
\text { innovations } \\
\text { - exchange of materials \& } \\
\text { experiences }\end{array}$ & $\begin{array}{l}\text { - official } \\
\text { implementation }\end{array}$ \\
\hline $\begin{array}{l}\text { professors \& } \\
\text { teachers }\end{array}$ & volunteer schools & all basic schools \\
\hline
\end{tabular}

Figure 1. Process of the curriculum reorganization.

A decade after its implementation, we can say that the curriculum was in line with the great educational innovations of that time: a curriculum that is experimental and negotiated (Elbaz, 1993); a curriculum that attaches value to teachers' practical knowledge (Carr \& Kemmis, 1986), and that justifies teachers' work as curriculum makers (Connelly \& Clandinine, 1986). Furthermore, current analysis of the science curriculum shows that this curricular organization is aligned, even today, with the curricula of the best positioned countries' concerning international assessment of students' science competences (OECD, 2007). Indeed, an analysis of the science curricula of five of the best positioned countries (Hong-Kong, Taiwan, Finland, Netherland, New Zealand) revealed that all of them value the active involvement of students in their learning process and recommend science teachers to use diverse teaching strategies, such as inquiry activities, problem solving and field work, aiming 
the development of a set of transversal competences that allow students to make informed decisions related with science and society (Freire et al., in prep.).

However, despite significant improvements in international assessment (OECD, 2010), Portuguese students still do not perform as well as we would expect, considering the characteristics of the science intentional curriculum. This apparent contradiction, motivated the development of a national study aiming to evaluate the science curriculum of the 3rd cycle of basic education, with the goal to understand how teachers interpret and implement the curriculum and to identify students' achieved and experienced curriculum. Considering one of this chapters' goal - to understand the process of appropriation of new curricular concepts, we will focus on teachers' perspectives, aiming at describing how teachers interpret and implement the science curriculum of the 3rd cycle of basic education and at identifying what factors affect the way they interpret and implement it. Furthermore, as we intend to capture the process of appropriation of the new concepts and of the enactment of the new principles, we analyzed a set of studies that have been developed with the goal to picture some aspect of the curricular reorganization, as it will be described next.

\section{Interpretation and Implementation of the Science Curriculum: Teachers'}

\section{Perspective}

\subsection{Methodology}

In order to know how teachers interpret and implement the science curriculum and to understand the process of appropriation of new curricular concepts, we conducted a 
complex overall research which analyses data collected in the context of different studies:

- Nationwide study focused on teachers' perspectives regarding the science curriculum;

- Several comprehensive studies, spread over different parts of the country and performed in different periods of the time interval considered (since the official adoption of the documents).

The nationwide study aimed to understand the perspectives of teachers on the science curriculum, including describing how teachers interpret the curriculum documents and how they implement the proposals made. Data was collected through the application of questionnaires that were administered to a representative sample of 698 teachers (395 PCS teachers; 394 NS teachers). Most of the teachers who responded to the questionnaire were female (80\%) and has a background in education (75\%). Their ages range from 25 years to 50 years. $95 \%$ of teachers acknowledged that they know the national curriculum document and 97\% said they know the national curriculum guidelines for Physical and Natural Sciences for the 3rd cycle. About $69 \%$ of teachers stated his/her satisfaction with the science curriculum guidelines document.

The comprehensive studies aimed to understand the complexity of relationships and factors that interfere with the interpretation and implementation of the curriculum and its impact on students' learning. Moreover, we intended to capture also the evolution of the process of appropriation of the curriculum since its official implementation. In order to accomplish these goals, we conducted a multiple case study, which encompassed five separate schools in the country (which took place in 
2011/2012), through which we explored in more depth all these aspects. Furthermore, we analysed data collected by several studies conducted in Portugal. These studies are mainly masters and doctorate, existing in institutional repositories, and they have been developed since the official implementation of the science curriculum (10 studies analysed). Finally, we analysed a study conducted in the early stages of the process of curricular reorganization (Galvão et al., 2004), which had as main objective to disseminate new ideas underlying the curricular reorganization, and to collect information about the perspectives of teachers on new proposals, as well as on the difficulties that they anticipated or that they experienced while they tried to implement the new proposals.

So, the data presented on this chapter will rely on the analysis of twelve distinct studies well developed across different years (see Table 1). It should be noted that the studies analyzed followed different research methodologies. While some studies were based on significant teachers' samples, other studies were qualitative in nature, focusing on a deep exploration of only a few cases (teachers). Thus, in the interpretation of the results we were especially careful and took into consideration that these studies are like pieces of a puzzle, which together allow us to create an image of what will be or have been a process of appropriation of the new curriculum by the teachers. 
Table 1.

Description of the studies included in the analysis of comprehensive studies.

\begin{tabular}{|c|c|c|c|c|c|}
\hline References & $\begin{array}{l}\text { Date of data } \\
\text { collection }\end{array}$ & $\begin{array}{l}\text { Method of data } \\
\text { collection }\end{array}$ & Participants & District & Focus \\
\hline Viana (2003) & $2001 / 2002 *$ & Interview & $\begin{array}{l}\text { PCS teachers } \\
(n=6)\end{array}$ & Lisbon & $\begin{array}{l}\text { Classroom } \\
\text { practices }\end{array}$ \\
\hline Galvão et al. (2004) & $2003 / 2004$ & Questionnaire & $\begin{array}{l}\text { NS and PCS } \\
\text { teachers } \\
(\mathrm{n}=53)\end{array}$ & Lisbon & $\begin{array}{l}\text { Concepts and } \\
\text { practices } \\
\text { about } \\
\text { curriculum }\end{array}$ \\
\hline Sítima (2005) & $2003 / 2004 *$ & Interview & $\begin{array}{l}\text { Pedagogical } \\
\text { pair (NS and } \\
\text { PCS teacher) } \\
(n=2)\end{array}$ & Lisbon & $\begin{array}{l}\text { Collaboration } \\
\text { between } \\
\text { teachers }\end{array}$ \\
\hline Abelha (2005) & $2004 / 2004$ & Interview & $\begin{array}{l}\text { NS } \\
\text { department } \\
(\mathrm{n}=1 \text { school })\end{array}$ & Aveiro & $\begin{array}{l}\text { Collaboration } \\
\text { between } \\
\text { teachers }\end{array}$ \\
\hline Correia (2006) & $2004 / 2005^{*}$ & Interview & $\begin{array}{l}\text { PCS teachers } \\
(n=3)\end{array}$ & Lisbon & $\begin{array}{l}\text { Concepts and } \\
\text { practices } \\
\text { about } \\
\text { assessment }\end{array}$ \\
\hline Ferreira (2006) & $2004 / 2005$ & $\begin{array}{l}\text { Interview; } \\
\text { Questionnaire }\end{array}$ & $\begin{array}{l}\text { Pedagogical } \\
\text { pair ( } \mathrm{n}=126 \\
\text { schools) }\end{array}$ & Aveiro & $\begin{array}{l}\text { Practice of } \\
\text { co-teaching }\end{array}$ \\
\hline Júlia (2006) & $2004 / 2005^{*}$ & Interview & $\begin{array}{l}\text { NS and PCS } \\
\text { teachers }(n=8)\end{array}$ & Lisbon & $\begin{array}{l}\text { Inquiry } \\
\text { activities }\end{array}$ \\
\hline Raposo (2006) & $2004 / 2005^{*}$ & Interview & PCS teachers & Faro & Concepts and \\
\hline
\end{tabular}

Version pre-printed from the chapter of the book Akpan, B. (ed.). Science Education: A Global Perspective (pp. 228-252). Springer. ISBN 978-3-319-32351-0 (2017). 


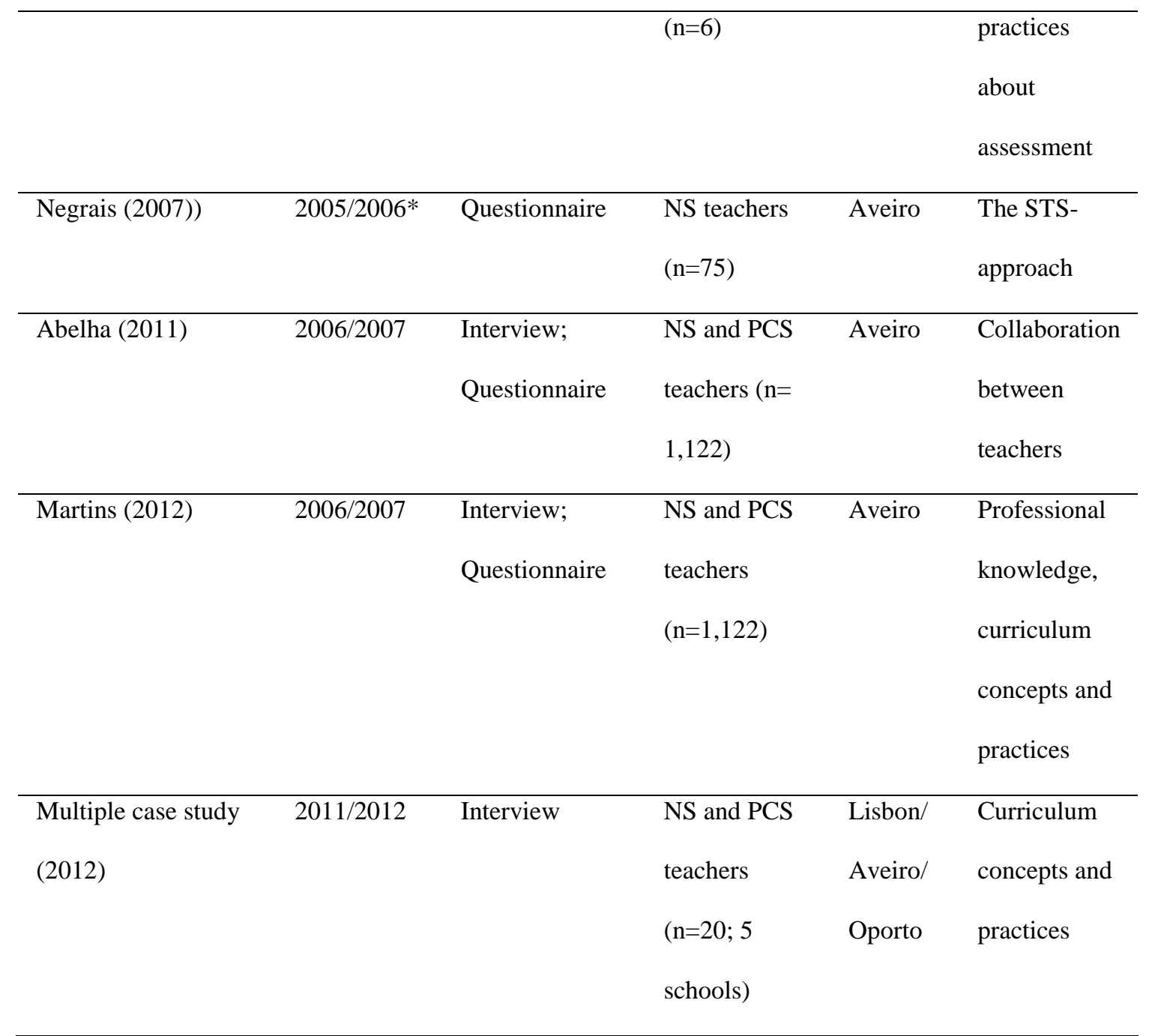

Note: (*) Date of data collection not confirmed.

\subsection{Results}

The results are organized according to two major innovations advocated by the new curriculum reorganization: a) the idea of flexible management of the curriculum, which requires a culture of collaboration and articulation between the teachers; b) the development of learning experiences for enacting students' competences and revised assessment.

Version pre-printed from the chapter of the book Akpan, B. (ed.). Science Education: A Global Perspective (pp. 228-252). Springer. ISBN 978-3-319-32351-0 (2017). 


\subsubsection{Flexible management of curriculum}

One of the intentions of the curriculum reorganization was that teachers would break away with their routine and individualistic way of working and would develop collaborative work with other teachers. The idea was that by assuming themselves as curriculum makers, teachers would make strategic and intentional decisions about curriculum organization and learning situations, using their professional knowledge of the context and of the students. The ultimate expected goal was to promote successful learning of all students and the development of recommended competences (DEB, 1999). For this, teachers had to break away with the traditional model of school, based on a transmissive pedagogy and with an individualistic culture of teaching (Formosinho \& Machado, 1998). In order to facilitate this change, several curricular management structures were created, namely the class council, responsible for designing and managing the class curricular project (DEB, 1999). It was expected that the class council would facilitate, among other aspects, the coordinated management of the different academic subjects and, at the same time, that it would facilitate teachers' collaboration in common projects (DEB, 1999).

The results that emerge from our study reveal that the curriculum reorganization did enhance some changes in what concerns teachers' collaboration with each other in making curricular decisions. However, the observed changes are frequently not aligned with the original intentions of the curricular documents.

Data obtained in the nationwide study shows that most teachers refer they usually work in collaboration only with colleagues of the same academic subject (52\%), and preferably with colleagues who teach the same subject at the same grade $(63 \%)$. 
Furthermore, data shows that they mainly collaborate in planning the classes (78\%), in defining criteria for students' assessment (89\%), in planning field study (79\%), in preparing materials (71\%), and in planning laboratory activities (70\%) and interdisciplinary activities $(71 \%)$.

Similarly, the comprehensive studies reveal that, in general, the collaboration of teachers is based primarily on the exchange of learning materials and experiences, field studies organization, and assessment instruments. Besides, teachers teaching the same subject, either at the same grade or different grades, collaborate more often with each other. As one teacher of the multiple case study mentions, "There is sharing of information. Nobody is hiding anything. Nobody is afraid to share”. In addition, comprehensive studies reveal that teachers' collaboration is occasional and informal, as can be observed in the following excerpt,

When anything happens, we, even informally, do a meeting in the staff room. As we are only three, it is very easy for us to come together in a corner, for discussing our ideas. Many times, we do it in an informal way. (Multiple case study)

Nevertheless, formal and institutional collaboration is also stimulated. The study of Abelha (2011) shows that the class curriculum project did enhanced formal moments of collaboration among teachers. However, there was not an authentic collaborative involvement with the class curriculum project, as it was understood as being under the exclusive responsibility of the class director. The same lack of involvement with the meetings, where teachers would supposedly make joint decisions concerning the curriculum, was observed in Martins (2012) study. Based on their observations, both authors conclude that these formal curriculum management tools seems to be working 
as instruments devoid of meaning, being experienced by teachers as one more bureaucratic aspect.

Finally, most times, flexible management of the curriculum is understood as a means to decide when and at what level of depth should each subject be addressed and explored, in order to circumvent what teachers consider to be the extent of the curricula problem and the repetition of topic problem. This operating philosophy is well captured by one of the interviewed teachers of the multiple case study. He refers that:

Articulation is usually discussed during the meetings. Each one of us shares with the others the current topic that he is exploring on that moment. Then, we try to cross information, in order to, as far as it is possible, save time. Indeed, some topics are addressed in geography, science, physics and chemistry. Our intention is to save time. And also we want to show the universality of knowledge. (Multiple case study)

Consistently, results from comprehensive studies point also to an articulation between NS and PCS subjects focused primarily on adjustments to the content level and the informal exchange of materials, experiences and ideas, as can be observed on the following excerpt,

We combine more or less what each one of us teaches, for not repeating themes. We have to do that, due to some repetitions of the curriculum. For instance, in natural sciences (NS) we first explore the genesis of the heliocentric theory, but in physics-chemistry sciences (PCS) it is the other way round. We, for example, explain pollution in the eighth grade, and then my geography colleague explains it again later! (Multiple case study)

One important innovation of the reorganization of the science curriculum of basic education was having bridged NC and PCS. It was intended that teachers explore the NC and PCS curricula in an articulated way, making coordinated decisions on how to 
organize and explore the content and planning of educational experiences and jointly develop activities with students (DEB, 2001b).

These were positive aspects pointed by teachers in the early stages of the process of reorganizing the curriculum (Galvão et al., 2004). However, simultaneously, teachers anticipated as one of the greatest difficulties in implementing the new curriculum, exactly, the joint work that was asked of NC and PCS teachers and the development of articulated learning experiences. In their view, the difficulties anticipated were in aspects related to the organization of the school (including schedules, reducing the time allocated to each discipline, as well as the lack of resources) and in issues related to the time required to do things according to the curriculum (and lack thereof) (Galvão et al., 2004).

These same difficulties have been identified in several of the comprehensive studies developed afterwards. In addition, one more aspect repeatedly pointed out by teachers to explain the absence of more concerted practices among them is related to the characteristics that they attach to the national curricular guidelines for PCS and NS, namely programmatic disarticulation, the difficult of articulating the content and its extension (Abelha, 2011; Ferreira, 2006; Martins, 2012; Sítima, 2005). Results from the multiple case study are coherent with these ones: teachers point to the vagueness of the curriculum documents and value, in opposition, the textbooks because it highlight ways to proceed, far more concrete and objective.

Besides this aspect of vagueness, some teachers show an ambiguous stance regarding the curriculum: teachers feel that if they do according to what is prescribed in 
the curriculum, they will not have time to teach contents. As stated by one of the teachers,

In order to fulfill the program, we have to make options: either we do not teach anything. In this case, we fail because we didn't effectively meet the content that we were expected to; or we rather follow a more restrictive guidance, in order to effectively teach them something more concrete. In this case, we follow the logic proposed by the textbook and the textbook itself. (Multiple case study)

Aligned with this, another teacher says, "Because if we organize the teaching process according to the curricular guidelines, then I think that even 180 minutes are not enough" (Multiple case study). These considerations about the curriculum documents had been already woven by teachers in the early stages of discussion of the new curriculum. Indeed, these teachers foresaw difficulties related to the time required to develop the curriculum in line with the proposals, time which they considered do not have due to the reduced hours that were attributed to NS and PCS classes (Galvão et al. 2004).

In conclusion, the type of actions that teachers refer to develop, as well as the difficulties associated with the new curriculum proposals, seem to be based on conceptions that do not fit in with the ideas underlined in the curriculum reorganization. Indeed, the results obtained through the various studies indicate to limited views of teachers on flexible management of curriculum, primarily associated with the management of time and subjects, in order to successfully fulfil the program. Similarly, the curriculum articulation is viewed essentially as a way to gain time and avoid repetitions. There therefore seems not to be a joint pedagogical work, with a marked intentionality. Thus, in conclusive terms flexible curriculum management is not fully understood as a means of making coordinated decisions focused on the needs and 
characteristics of students, in order to promote meaningful learning and the integral development of students. Besides, the way teachers enact the flexible curriculum management suggest that they don't see themselves as curriculum makers, as was the original intention of the curriculum.

\subsubsection{Learning situations to develop competences}

This way of understanding and enacting the curriculum, in the specific case of the sciences, seems also to be rooted in a specific view on science education and its purposes, which is not in accordance with the ideas advocated by the new curriculum proposal.

One of the innovation of the national curriculum was to challenge the conception of knowledge as "something static and as something external to people, as a product, as the truth that is not questionable, organized in a compartmentalized and linear way, and non-contaminated by values" (Alonso, 2005, p. 17), and to replace it by the notion of student as an active and autonomous producer of its own learning process (Alonso, 2005). However, studies suggest that frequently teachers' understanding of some of the ideas of the curriculum is superficial, or it is not aligned with the original intentions, affecting their practices in a very precise way.

The study by Martins (2012), with data collected in 2006/207 with a sample of 1,122 teachers of the 2 nd and 3rd cycle of basic education, reveals a very particular situation. Most teachers recognize the term competence formulated in accordance with the subjacent philosophy of the curriculum. However, this familiarity with the concept is not followed by deep changes in these teachers' practices. In comparison, the multiple 
case study shows that despite the term competence is frequently used in the various school documents, it is largely absent from the discourse of the surveyed teachers. Of the 20 interviewed teachers, only five used the term competence in his/her speech. Furthermore, competence is understood as something vague that students must acquire and that teachers have the duty to provide the students with. For example, one of the teachers states "if we demand too much from the students, many of them will not achieve the competences in the end. They will go out only with some general competences related with the disciplines" (Multiple case study). Another teacher mentions that "there is a whole set of competences that they could acquire and after that would be useful in day-to-day" (Multiple case study). The emphasis is on acquiring competences and on equipping students with them, with an underlying perspective of 'learning as acquisition", rather than learning as a process constructed by the student, which is the underlying conception of the curriculum.

So despite, the wide dissemination of the term in the school documents, and even despite some familiarity with the term, in general the notion of competence is not fully comprehended by the teachers, who haven't change their practices accordingly. In what concerns assessment practices, the study of Viana (2003) shows that despite the surveyed teachers have introduced some new practices derived from the new curriculum guidelines, the results reveal a situation where in fact the views and beliefs concerning teaching and science education purpose has not changed. Indeed, these teachers referred that they make lessons less expositive, use new materials, develop more experiences, stimulate more debate and more inquiry activities. However, their assessment instruments and methods remained unchanged. Similarly, Raposo (2006) and Correia 
(2006) observed a mismatch between the assessment practices and the development of competences that teachers claimed to promote. So, basically surveyed teachers use written tests, worksheets, observation and mental records (to assess attitudes), and focus on the assessment of knowledge, emphasizing some procedural and communicative competences. However, they still overvalue the summative assessment and they still pose greater emphasis on contents.

The nationwide study shows that only a small proportion of teachers do as recommended in the curriculum documents. Indeed, only $32 \%$ of teachers uses frequently classroom discussions, concept maps, students' observations, students' oral responses and portfolios (this group differs statistically from the rest of the teachers; ( $p$ $<0.001)$. These small proportion of teachers also use more students' self-assessment practices, written reports on experimental activities, research works $(\mathrm{p}<0.01)$ and homework $(\mathrm{p}<0.05)$ for assessing students. Regarding written tests, these teachers include more often, than the overall sample, items requiring an explanation, elaboration of texts, construction of graphs $(\mathrm{p}<0.01)$, interpretation of experimental results, argumentation, interpretation of graphs, tables and texts, planning investigations and enunciation of hypothesis $(\mathrm{p}<0.001)$. Finally, these teachers inform more frequently students about their learning objectives, involving them in its identification, assign more frequently differential work depending on students' results on assessment, use performance level descriptors in assessment, and provide more frequently opportunities for students to reflect on their work $(\mathrm{p}<0.001)$.

With respect to the practices themselves, several studies reveal a complex situation. Regarding the strategies recommended in the science curriculum, the 
nationwide study show that most teachers referred that they implement inquiry activities (86\%), project work (68\%) and experimental work (85\%) only in some of the classes (Figure 2). There are fewer consensuses on the activities related with decision making and problem solving. In the first case, $50 \%$ of teachers said they use decision making just on a few classes and about $25 \%$ said they use activities of this nature in almost every class. In the case of problem-solving activities around $49 \%$ of teachers said they use this type of activities in almost every class.

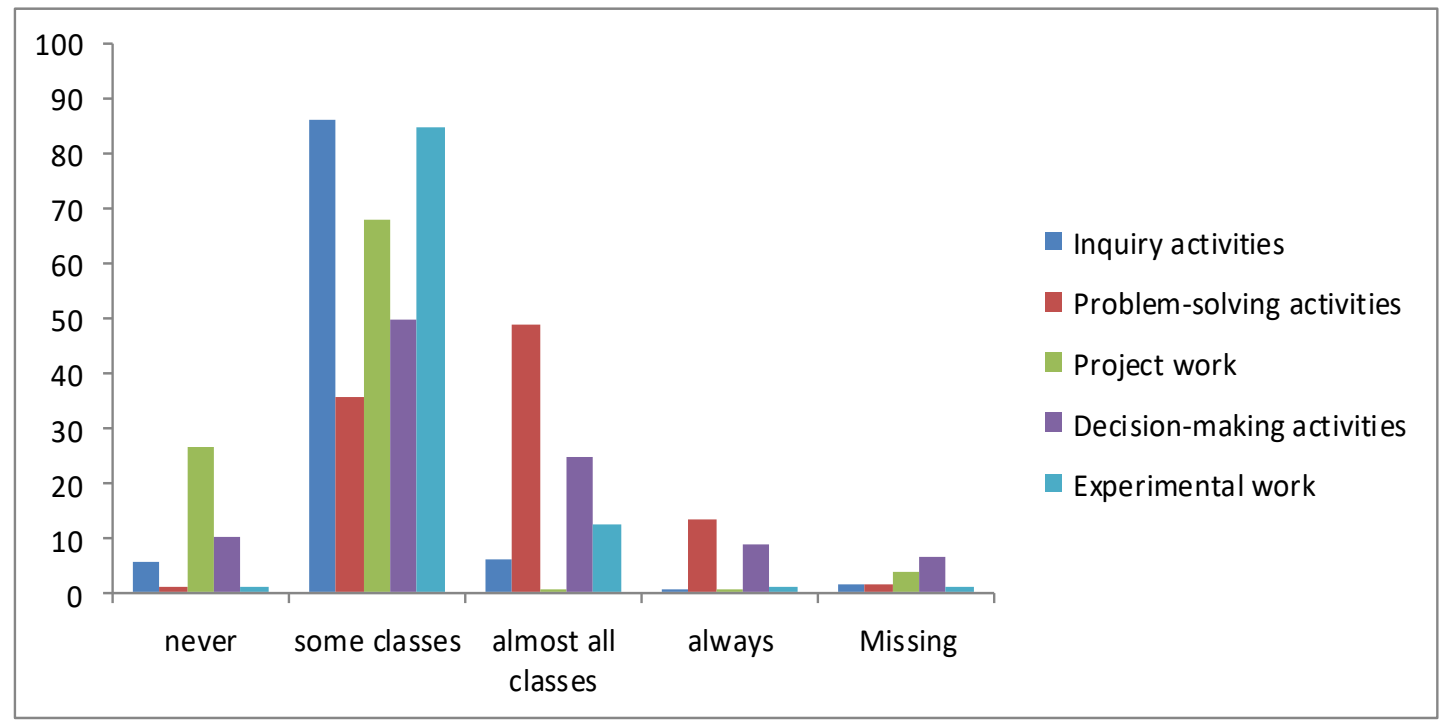

Figure 2. Frequency of implementation of the different strategies.

So, the nationwide study reveal that most teachers (68\%) seems to follow a more traditional methodology, i.e. they rarely use a) strategies related to inquiry activities (such as identifying a problem, formulating hypotheses, interpreting data, producing texts, using models, constructing graphics based on data, arguing and debating ideas, observing natural phenomena, planning investigations), b) strategies related to STS 
issues (such as discussing controversial issues, studying issues that affect society welfare, reading texts such as biographies and/or scientific discoveries), and c) strategies related to experimental activities (such as conducting experiments, reporting on experimental activities, oral presentation of the results of the experiments).

Mention should be made that about 221 of the surveyed teachers (32\%) referred that they frequently use (in almost all classes) such strategies; mainly those related to inquiry activities and to STS issues. These teachers use more frequently inquiry $(\mathrm{p}<0.001)$, problem solving $(\mathrm{p}<0.001)$, project work $(\mathrm{p}<0.01)$, decision making $(\mathrm{p}<0.001)$ and experimental work $(\mathrm{p}<0.001)$ strategies, than the others teachers.

So, this small percentage of the overall sample seems to follow the general guidelines of the science curriculum. However, about $70 \%$ of science teachers in Portugal seem to follow a more traditional teaching practice. These results are consistent with those obtained in the other studies. For instance, in the study of Martins (2012) about half of the respondents refer that they have changed their practices, particularly in terms of: (i) use of information and communication technologies according to the different situations, (ii) organization of debates related to STS situations, (iii) integration of multidisciplinary knowledge in the context of the classroom, (iv) use of strategies that relate Science, Technology and Society, and that promote a higher degree of autonomy in students, (v) implementation of teaching methods and strategies that promote competences development in and with students and (vi) promotion of critical analysis of news published by the media.

However, these changes reveal, according to Martins (2012), a scant appropriation of the concepts, in the context of developing articulated and strategically defined 
curricular practices, as well as in the context of creating learning experiences that promote competences development in students. In fact, results obtained in her study reveal that the decision-making is strongly influenced by aspects related to the fulfilment of the academic program.

In line with the study by Martins (2012), the teachers surveyed in the other comprehensive studies show a positive attitude regarding some of the proposals of the new curriculum (namely the STS-E dimension, the experimental, inquiry and problem solving activities, debates and bibliographic research). However, as in the study by Martins (2012), it is observed that the appropriation done by teachers is very superficial and even different from the original intentions. For example, in her study focused on the STS-E dimension, Negrais (2007) noted that the surveyed teachers valued the dimension STS-E as a way to develop competences and critical citizenship, and that they refer doing more debates, more problem solving activities, and exploring more the connections between scientific concepts and the daily world. However, these teachers do not value activities developed outside the context of the classroom, do not explore topics in an interdisciplinary way, nor even have changed the form of assessment, and as such still pose great emphasis only on content.

Similarly, Julio's (2006) teachers express positive attitudes in what concerns experimental activities. However, the type of experimental activities developed are restricted to those proposed by the textbook, rely upon in a closed protocol, do not involve control of variables nor they imply reflection and debate.

The same practices and underlying conceptions were identified in the multiple case study. Indeed, many of the surveyed teachers mention that they carry on debates 
and bibliographic research activities, problem solving activities, and that they implement some practical classes where they develop demonstration activities, experimental work, inquiry activities, and some field work. Other teachers reported the importance of linking science to students' daily lives as a way to motivate them. For instance, one of the teachers explains,

Sometimes [students] do not realize why they are going to study those things. And then, I usually bring ... for example, we are now studying earthquakes and volcanoes. I'll get news and reports. "So now you know what is meant to say that: -'on the Richter scale, ...'. So it is for them to understand the news... (Multiple case study)

But again, the choice of this type of activity does not seem to involve real strategic and pedagogical options, but essentially the motivating aspect. This aspect is very prominent in the way the following teacher described a chemistry experiment: "Then, in chemistry when we study the alkaline metals, I do those explosions, and they consider it very amusing, isn't it?" (Multiple case study). Another teacher exposes his ideas concerning field study: "I like to take in students and go to the garden. We pick the ants and it is very funny. It turns out to be a practical lesson "(Multiple case study). Where there is a concern about the learning, the focus is to facilitate the understanding of the concepts and theories. Again, there is an emphasis on the products of science to the detriment of processes and knowledge about the nature of scientific knowledge and scientific activity, which promote a general understanding of science and contribute to the development of students' scientific literacy (Galvão \& Freire, 2004), one of the purposes of science education, today, and one of the goals explicit in the science curriculum. 
This overemphasis on content seems associated to a traditional and limited conception about science education, which devalues the development of attitudes (of wonder, questioning, respect for evidence), the understanding of the nature of scientific knowledge and scientific activity (with its practical component, yes, but mainly with its rational component of questioning, inductive and deductive reasoning, argumentation, etc..) and the understanding of the complex relationships that are established between science, society and technology. Now, these are the explicit aims of the new curriculum documents (Galvão \& Freire, 2004).

The study conducted with teachers early in the process of curriculum reorganization (Galvão et al., 2004) evidenced already a similar scenario. In this study, surveyed teachers criticize the undervaluation of scientific knowledge and an education too focused on student learning experiences, revealing a misinterpretation of what were the original intentions of the curriculum. Authors of the study conclude as follows,

[There is a] lack of understanding of what is considered nowadays to be the actual concept of science teaching. In their criticism, the teachers reveal a static perspective of science, overvaluing the products of science and undervaluing other components. The objection of some teachers shows their criticism of the proposed educational experiences, because they feel these undervalue the transmission of scientific knowledge and give more importance to the learning experiences that are more pupil-centred, based on a constructivist perspective of learning. Sometimes, in the criticism made by certain teachers regarding the Curricular Guidelines, they value previous practices and do not seem open to the potential of teaching oriented towards the development of competences. They adopt the different jargon, but do not change their practices. (Galvão et al., 2004, p. 64)

The confrontation between a science education focused on content (facts and theories) and competences works as a justification for not implementing a set of learning experiences as often as it would be desirable. Indeed, Martins (2012) concluded that 
The extension of the programs, the curriculum organization by disciplines, the limited cooperation among educational stakeholders, including students' families, and an alleged lack of working conditions, were the main constraints appointed for the development of a curriculum organized by competences. (p. 206).

Indeed, a constraint rather appointed by teachers is related to the extension of the curricular program and the need to comply with it, as evidenced in the following statement by a teacher in the study of Martins (2012):

Indeed competences acquisition is not performed with the desired frequency. This is due to the fact that the curricular programs are very extensive. Having the obligation to comply them, then it is not always possible to analyse day-to-day problem-situations involving curricular content knowledge. Furthermore, the acquisition of competences implies that students acquire the knowledge necessary for the resolution of the problem-situation, and students do not always master the content taught. (p. 258).

This argument, once again, reflects the excessive preoccupation of teachers with the content, as reflected in the following excerpt from an interview with a teacher:

I do problem solving and experimental activities on some occasions. Expository lessons too, more frequently. The situation is as such: or we teach the entire program, and on that case we have to rely on expositive lessons; otherwise we will not accomplish it. Or we do according to the proposed innovations and we will not be able to teach the entire program. Dialogues and debates are OK. In what concerns exercises, students usually take them home as homework and I have only to correct it in the class, and so I do not waste so much time. It is to be like this, for not failing to fulfil the program. (Multiple case study)

Both statements reveal a very usual situation. Teachers frequently confuse curricular program (which enumerates all contents too be explored in a certain cycle of education or grade) with curriculum. Curriculum, as understood within the national curriculum reorganization, is a set of apprenticeships that students are expected to make, a set of guidelines concerning how those apprenticeships should be organized and their role within students educational development as well as, in a different dimension, the 
learning situations designed by the teacher, in order to involve the students and to promote their successful learning (Abrantes, 2001; Roldão, 1999). So in this sense, the curricular program is a tool of the curriculum; it is not the end in itself but a means to enact a set of apprenticeships, the context from which teachers design learning situations (Abrantes, 2001; Roldão, 1999). However, teachers' excessive preoccupation with teaching all the topics presented in the program deviates them from the real intentions of the curriculum: to create learning experiences, considering the disciplinary topics, in order to facilitate competencies' development.

Another constraint pointed out in several studies, are the students' difficulties and lack of motivation. Indeed, in general, teachers feel that students have very significant gaps in different areas (both in terms of their specific basic science knowledge, and in terms of cross-cutting areas such as math, reading and interpreting texts). However, students' difficulties are never seen as the result of certain actions or teaching practices, but as a reason for them not to do according to what is recommended by the curriculum. The results obtained in the multiple case study suggest that given the difficulties of writing, reading and interpretation of texts, rather than creating learning situations that facilitate the development of these competencies, teachers develop more self-centred expositive teaching, focused on the transmission of simplified content. This form of perceiving the lack of student motivation and their difficulties and how they affect the decision making of teachers reveals, once again, a teacher who does not take itself as a reflective practitioner, who does not uses his/her knowledge and experience in an intentional strategy to achieve its goals and assesses the results and who does not takes a 
critical attitude about his/her practice, being able to understand the causes of success or failure.

\section{Final Considerations}

The national curriculum of basic education has introduced a number of innovations that aimed to cause a conscious change in the education system in order to improve it. Nevertheless, educational research reveals that change requires a concerted work on several levels. It implies changing teachers' conceptions and practices, changing students and parent's beliefs concerning education and even changing the educational system, for instance the national assessment systems (DeBoer 2000; Osborne \& Collins 2001). Educational change implies that teachers understand expected changes and appropriate new competencies in order to be able to implement them (DeBoer 2000).

Several authors (Altrichter, 2005, Snyder et al., 1992) point out that if teachers feel that an innovation is relevant and that for this reason, it is important to change their practices, the successful implementation of the curriculum increases. So in the first place teachers have to be given clear and meaningful objectives. In this sense, it is essential to monitor the process of change, creating structures capable of responding to the training needs of teachers, related to the proposed innovations of the curriculum, by providing materials and resources to accomplish these innovations in the classroom and providing them the feedback of the work they are developing (Fullan, 2008). And for this it is necessary to involve teachers in the change, get them to reflect on their practices and conceptions about the desired changes and on the effects of their changes 
in the students, in a complex interplay going back and forth, of action-reflection-actionreflection (Galvão, Reis, Freire \& Almeida, 2011a).

This curriculum has been designed and implemented based on the assumption that the teacher does not play directly and passively the guidelines. Rather, teacher transform, reinterpret those guidelines in light of his/her knowledge, experiences, and conceptions about the teaching process, the teachers' role, the goals of education and in the light of his/her specific educational context. This was a main assumption of the national curriculum reorganization: curriculum development understood as "a gradual and continuous process, involving observation, reflection and adjustment of guidelines and pedagogical practices" (Abrantes, 2001, p. 44).

So, the process of curriculum reorganization, which enclosed a deep process of innovation, sought to involve from the beginning the teachers and schools. Furthermore, there was an initial follow up in order to help teachers to overcome difficulties, to clarify concepts, to make rethinking visions, to develop new knowledge and competencies, but also to register their comments, appreciations and based on these, to rethink adjustments to the curriculum (Galvão et al., 2004). After this initial process, the curriculum development process was broken abruptly as a result of a shift in priorities and political agenda. Indeed, there was a change in the Portuguese government and as a result there was a change of policy, namely concerning the process of implementation. So, the formal monitoring of the process of change ended. Nevertheless there continued to register occasional initiatives of collaboration among teachers/schools and teacher training institutions, which helped some teachers to implement the new guidelines. Despite these occasional initiatives, most of the Portuguese in-service teachers ended up 
being imposed with a set of top-down guidelines. And so the teachers were alone in this change process. This is the situation opposite to what educational research points as important. Altrichter (2005) refers that an innovation promotes changes in organizational structures and, as such, it is extremely important to foster a connection between political structures and schools to carry out the implementation of a curriculum (Snyder et al., 1992).

It was assumed the figure of the teacher as a reflective practitioner, highly qualified to interpret and implement new ideas in alignment with the original purposes. It was assumed that teachers were holders of a set of knowledge that would allowed them to interpret and implement the new proposals, according to the original intentions. However,

Moving from a culture based on teaching the curriculum program, following the textbook, transmitting knowledge, and assessment based on tests, to a culture focused on promoting competencies, implies a profound reconceptualization of the way we understand the processes of learning and forms of organization of the work of teaching and learning (Alonso, 2005, p. 26).

In order to deal with the new requests, and moving within specific and broader educational contexts, teachers took up resources that were familiar to them to respond to these requests. In this process they rejected some of the proposals on grounds consistent with their conceptions and they accommodated other proposals to what were familiar to them. By requiring a teacher's posture radically different from its traditional posture and by requiring different professional knowledge and competences, the ideas of flexible management of the curriculum and the creation of learning situations for the development of competences were aspects rejected by many teachers. For justifying their actions, which were not aligned with the new demands and expectations, teachers 
used a set of arguments, mainly external (but often internal, for instance, when teachers recognize limits in their training). Huberman, already in 1973, mentioned that "history shows that education is a domain in which the gap between the new and old is almost never clearly filled", giving meaning to the idea that in order for the changes to succeed, they cannot radically put into question previous acquisitions (Crozier, 1982).

These findings contradict some psycho-sociological theories, according to which individuals (or groups or institutions) have an innate need to alter the individual balance moved by a sense of curiosity and invention. In comparison, systems theory states that social systems are stable and homeostatic, meaning that after minor disturbances they return to an equilibrium state similar to the previous condition. Systems are characterized by the principle of self-regulation through which they can meet the demands of the environment without undergoing profound changes. Thus, schools as institutions are, by nature, confronted with this contradictory aspect: the will to remain unchanged and the willingness to change. They are oscillating systems, according to the concept of Enriquez (1972). And so, for being able to break away with the tradition, and to make themselves learning organizations (Senge, 1990), schools require strong impulses, emerging simultaneously from the external pressure (at the level of educational policy) and the internal pressure (the movement of teachers and school management directions).

Looking at what happened in Portugal, even for those teachers who invested in change, without other support to help them reorganize ideas and the school system, teachers re-appropriated some of the concepts. However, according to some authors of the studies presented (Abelha, 2011; Martins, 2012; Martins et al., 2008, 2011), this re- 
appropriation of concepts was made only superficially. In our view, this was the possible appropriation, taking into account the internal resources of teachers, i.e., their knowledge, their competencies, their conceptions, and even their context, where they often had to fight against a rigid and bureaucratic school organization which was suspicious of the new proposals.

So, there were some aspects - namely, some classroom teachers' practices, which changed in a more comprehensive way. However this change in practice was once again based on the teachers' resources. Teachers modified certain practices, not according to the original intentions of the curriculum, but according to how they perceive education and the aims of science education, according to their knowledge and competences and how they perceive and experience some of the constraints. In the initial documents of the process of curriculum reorganizing, Roldão (1999) refers that,

Theoretical knowledge is the fundamental basis, but much more essential is to use it to learn to theorize situations, and to produce and to reconstruct knowledge from those situations. Otherwise, knowledge remains inert and information does not become "knowledge in use", which is than enacted in competences of actionreflection. (p. 84).

However, knowledge and competences of most of the teachers were built in a time other than the current one, and were based on different conceptions than that underlying curriculum re-organization.

Thus, our results show that the consideration of a school as a system, in which a network of effective communication is the basis of the propagation of changes, cannot forget the individual. The involvement of the different actors in the innovation process begins, according to the Concernes-Based Adoption Model (sensu Vandenberghe, 1986), by teachers becoming aware of the innovation, and then moving by the desire to 
know more about it, and by an active involvement with it, even facing several uncertainties. The involvement with the innovation then proceeds and focuses on the management of the process, promoting collaboration, and on the understanding of its different implications, especially for the classroom. Finally it culminates in the review of the innovative process, which frees the teacher to deal with larger and more radical changes. A transformation of this type requires great coordination, time and investment in teacher training. It also needs support at the educational policy level, who believes on the proposals, on the practical capability of teachers to put them into action and on the scope of those proposals.

Resuming the thought of Senge (1990), when we question the structures of our organizations, we also need to question our internal structures, our mental models. And for that, we need to work with teachers, helping them not to be afraid to look at their own limitations, and giving them time and space to take ownership of what is proposed. As refer Galvão, Reis, Freire and Faria (2011b),

Change is not easy, takes time and involvement in situations, confidence in who presents the new, support for dealing with emerging doubts and insecurities. (...) You have to be with teachers throughout the process, listen to their views, offer alternatives to them, and appreciate their accomplishments (p.68).

But it is also necessary that training institutions are open minded, so that they too can learn with the school practice, validating the practical knowledge of teachers, fostering collaborative networks of researchers and teachers, creating an organization based on systemic and interdisciplinary collaboration. The connection between schools and training institutions, in a symbiotic and mutual learning relationship, can be one of the ways to create communities of practice in which researchers and teachers are able to 
build a curriculum that should be open, flexible and aligned with current perspectives in science education.

\section{Acknowledgments}

Part of this study was supported by Fundação para a Ciência e a Tecnologia as part of the Project "Evaluation of the Physics and Natural Sciences Curriculum, third cycle of Basic Education” (PTDC/CPE-CED/102789/2008).

\section{Referencies}

Abelha, M. C. (2005). Cultura Docente ao nível do Departamento Curricular das Ciências: um estudo de caso. Tese de dissertação de mestrado Departamento de Ciências da Educação. Departamento de Didáctica e Tecnologia Educativa. Universidade de Aveiro, Aveiro.

Abelha, M. (2011). Trabalho colaborativo docente na gestão do currículo do Ensino Básico: do discurso às práticas. Tese de Doutoramento em Didática, Universidade de Aveiro, Aveiro.

Abrantes, P. (2001). Reorganização curricular do Ensino Básico: Princípios, medidas e implicações. Lisboa: Departamento do Ensino Básico. Ministério da Educação.

Altrichter, H. (2005). Curriculum implementation: Limiting and facilitating factors. In P. Nentwig, \& D. Waddington (Eds.), Context based learning of science (pp. 3562). Münster: Waxmann Verlag.

Alonso, L. (2005). Reorganização curricular do ensino básico; potencialidades e implicações de uma abordagem por competência. Actas do $1^{o}$ encontro de 
educadores de infância e professores do $1^{o}$ ciclo do ensino básico (pp. 15-29). Porto: Porto Areal editores.

AMA (2010). Critical Skills Survey. Retrieved in 29 March 2013, from: http://www.amanet.org/news/AMA-2010-critical-skills-survey.aspx.

Autio, O., Kaivola, T., \& Lavonen, J. (2007). Context-based approach in teaching science and technology. In E. Pehkonen, M. Ahtee \& J. Lavonen (Eds.), How Finns Learn Mathematics and Science (pp. 202-214). Rotterdam: SensePublishers.

Black, P., \& William, D. (1998a). Assessment and classroom learning. Assessment in Education: Principles, Policy \& Practice, 5(1), 7-75.

Black, P., \& William, D. (1998b). Inside the black box: Raising standards through classroom assessment. Phi Delta Kappan, 80(2), 39-148.

Carr, W., \& Kemmis, S. (1986). Becoming critical: Education, Knowledge and Action Research. London: Falmer.

Connelly, M., \& Clandinin, J. (1986). On narrative method, personal philosophy, and the story of teaching. Journal of research in science teaching, 23 (4), 293-310.

Correia, M. (2006). Concepções e práticas de avaliação de professores de Ciências $F / Q$ do EB. Tese de dissertação de mestrado. Universidade de Lisboa, Lisboa.

Crozier, M. (1982). Mudança individual e mudança colectiva. In R. KnoKe, E. Figueiredo. Mudança Social e Psicologia Social (pp.69-81). Lisboa: Horizonte.

DeBoer, G.E. (2000). Scientific literacy: Another look at its historical and contemporary meanings and its relationship to science education reform. Journal of Research in Science Teaching, 37, 582-601 
Departamento de Educação Básica [DEB] (1999). Gestão flexível do currículo. Lisboa: Ministério da Educação.

Departamento da Educação Básica [DEB] (2001a). Currículo Nacional do Ensino Básico - Competências Essenciais. Lisboa: Ministério da Educação.

Departamento da Educação Básica [DEB] (2001b). Ciências Físicas e Naturais Orientações curriculares para o $3^{\circ}$ ciclo do Ensino Básico. Lisboa: Ministério da Educação.

Elbaz, F. (1983). Teacher thinking: a study of practical knowledge. London: Croom Helm.

Enriquez, E. (1972). Problématique du changement. Connexions (4), 3-45.

European Commission, \& High Level Group on Science Education (2007). Science Education NOW: A Renewed Pedagogy for the Future of Europe (EUR 22845). Brussels: DG Research.

European Parliament and Council (EP\&C) (2006). Recommendation of the European Parliament and of the Council on key competences for lifelong learning. Official Journal of the European Union, L 394, 10-18.

European Union [EU] (2004). Europe needs more scientists. Report by the High Level Group on Increasing Human Resources for Science and Technology in Europe. Brussels: author.

Ferreira, A. M. (2006). A co-docência na área das ciências Físicas e Naturais: um estudo de caso. Tese de dissertação de mestrado. Universidade de Aveiro, Aveiro. Formosinho, J., \& Machado, J. (1998). Autonomia e Gestão das Escolas. Virtualidades e Contradições de um Compromisso Político. Braga: Universidade do Minho. 
Fullan, M (1982). The meaning of educational change. London: Cassell.

Fullan, M. (2008). Curriculum implementation and sustainability. In M. Connelly, M. He, \& J. Phillion, Handbook of curriculum and instruction (pp. 113-123). Thousand Oaks, CA: Sage Publications, Inc.

Galvão, C., \& Lopes, A. (2002). Os projectos curriculares de turma no contexto da Gestão Flexível do Currículo. In ME (Ed.), Gestão flexível do currículo reflexões de formadores e de investigadores (pp. 97 - 115). Lisboa: Ministério da Educação, Departamento da Educação Básica.

Galvão, C., \& Freire, A. (2004). A perspectiva CTS no currículo das ciências físicas e naturais em Portugal. In I. Martins, F. Paixão, \& R. Vieira (Eds.), Perspectivas Ciência-Tecnologia-Sociedade na inovação da educação em ciência. Actas III Seminário Ibérico CTS no Ensino das Ciências (pp. 31-38). Aveiro: Universidade de Aveiro.

Galvão, C., Freire, A., Lopes, A., Neves, M., Oliveira, T., \& Santos, M. C. (2004). Innovation in Portuguese Science Curriculum: Some Evaluation Issues. In ME (Ed.), Flexibility in curriculum, citizenship and communication/ Flexibilidade curricular, cidadania e comunicação (pp. 341-357). Lisboa: Ministério da Educação, Departamento da Educação Básica.

Galvão, C., Reis, P., Freire, A. \& Oliveira, T. (2007). Science curriculum in Portugal: From the development to the evaluation of students' competences. In D. Waddington, P. Nentwig, S. Schanze (Eds.), Making it comparable. Standards in Science Education (pp.237-253). Münster: Waxmann. 
Galvão, C., Reis, P., Freire, S., \& Almeida, P. (2011a). Enhancing the popularity and the relevance of science teaching in Portuguese Science classes. Research in Science Education, 41(5), 651-666.

Galvão, C., Reis, P., Freire, S., Faria, C. (2011b). Ensinar ciências, aprender ciências. Porto: Porto Editora, IE.

Júlia, V.N. (2006). Actividades investigativas no ensino das ciências. Tese de dissertação de mestrado. Universidade Nova de Lisboa, Lisboa.

Martins, I. (2012). O currículo das Ciências Físicas e Naturais na perspetiva docente, Saberes profissionais e possibilidades de acção. Tese de dissertação de mestrado. Universidade de Aveiro, Aveiro.

Martins, I., Abelha, M., Costa, N., \& Roldão, M. C. (2011). Impacto do currículo português das ciências físicas e naturais nas práticas docentes. Ciência \& Educação, 17(4), 771-788.

Martins, I., Abelha, M., Roldão, M. C, \& Costa, N. (2008). Impacte do Processo de Reorganização Curricular do Ensino Básico na área das Ciências Físicas e Naturais e na relação do professor com o trabalho curricular. Saber (e) Educar 13, 263-273.

Negrais, M. J. (2007). Percepções dos professores de ciências naturais cobre o ensino no âmbito CTSA. Tese de dissertação de mestrado. Universidade de Aveiro, Aveiro.

OECD (2007). PISA 2006: Science Competencies for Tomorrow's World, Volume 1: Analysis. Paris: OECD Publishing.

OECD (2010). PISA 2009, Results: Executive Summary. Paris: OCDE Publishing. 
Osborne, J. \& Collins, S. (2001). Pupils' views of the role and value of the science curriculum: a focus-group study. International Journal of Science Education, 23(5), 441-467.

Osborne, J., \& Dillon, J. (2008). Science Education in Europe: Critical Reflections. King's College London: The Nuffield Foundation.

Perrenoud, Ph. (1997). Construire des competences dès L'école. Paris : ESF éditeur.

Raposo, P. (2006). Concepções sobre avaliação das aprendizagens - um estudo com professores de $F Q$. Tese de dissertação de mestrado. Universidade de Lisboa, Lisboa.

Roldão, M.C. (1999). Os professores e a gestão do currículo. Perspectivas e práticas em análise. Porto: Porto Editora.

Senge, P. (1990). The fifth discipline. New York: Doubleday.

Sítima, M. A. (2005). Implementar colaborativamente o currículo de ciências físicas e naturais. Tese de dissertação de mestrado. Universidade de Lisboa, Lisboa.

Snyder, J., Bolin, F., \& Zumwalt, K. (1992). Curriculum innovation. In Jackson, P.W. (Ed.), Handbook of research on curriculum (pp. 402-435) New York, NY: Macmillan.

UNESCO-ICSU (1999). Declaração sobre a Ciência e o uso do saber científico. Paris: UNESCO.

Vandenberghe, R. (1986). Le role de l'enseignant dans l'innovation en education. Révue Française de Pédagogie. 75, 17-26. 
Viana, P. (2003). Perspectivas dos professores relativamente ao ensino de Física e Química preconizado pelas orientações curriculares para as ciências físicas e naturais. Tese de dissertação de mestrado. Universidade de Lisboa, Lisboa.

\section{Professional Biography}

Cecília Galvão (cgalvao@ie.ul.pt) is Professor of the Institute of Education of the University of Lisbon and the coordinator of the research group in Science Education. She coordinated the team responsible for the documents of Specific Competences in Physical and Natural Sciences, which integrates the National Curriculum and the Curricular Guidelines for Physical and Natural Sciences for the $3^{\text {rd }}$ cycle of Basic Education. Presently, she coordinates a national project aimed at evaluating the national science curriculum and she integrated the team responsible for the coordination of the Portuguese Learning Outcomes for the national curriculum.

Cláudia Faria (cbfaria@ie.ul.pt) is Professor of the Institute of Education of the University of Lisbon. She has a Ph.D. in Biology. She has published and been involved in research about Marine Biology and Science Education. Presently she coordinates a national project aimed at developing and implementing multidisciplinary activities using an integrated approach of different literacies within the classroom and non-formal institutions, such as science centers and museums. She also participates in a national project aimed at evaluating the national science curriculum. 
Sofia Freire (asraposo@ie.ul.pt) is Professor of the Institute of Education of the University of Lisbon. She is a psychologist with a Ph.D in Education. Presently, she is investigating in the area of science education and particularly, on the use of inquiry activities and its association to learning and competencies and attitudes development, and motivation. She has participated in several national and international projects and presently is member of a project which goal is to evaluate the national science curriculum.

Mónica Baptista (mbaptista@ie.ul.pt) is professor of the Institute of Education of the University of Lisbon. She has been involved in research projects related with science education and teachers' professional development. Presently, she participates in a national project aimed at evaluating the national science curriculum. She also participated in an European project called An Integral Teacher Training (IntTT). She has published and been involved in research about science education in different contexts and teachers' professional development. 